\title{
The Role of Child's Temperament Predictor on Preschool Social Competence
}

\author{
Sibel Yoleri \\ Department of Early Child Education, Faculty of Education, Uşak University, Uşak, Turkey \\ Email: yoleriizmir@usak.edu.tr \\ Received 16 May 2014; revised 19 June 2014; accepted 29 June 2014 \\ Copyright (C) 2014 by author and Scientific Research Publishing Inc. \\ This work is licensed under the Creative Commons Attribution International License (CC BY). \\ http://creativecommons.org/licenses/by/4.0/ \\ (c) $(1)$ Open Access
}

\begin{abstract}
This research has been conducted to examine the predictor effects that children's temperament traits have on the social competence variable. In total of 112 preschool children (57 boys, 55 girls), and their mothers and teachers participated in the study. To collect data, the Social Competence and Behavior Evaluation scale, short form (SCBE-30) as well as the Short Temperament Scale for Children were completed by their mothers and teachers. According to the results, there is a significantly positive relationship between the level of social competence and the persistence and rhythmicity level of temperament traits. In other results there was found to be a significant positive relationship between the level of anger/aggression and the reactivity temperament trait. According to the results of the multiple regression analysis social competence also has a significant effect related to temperament traits.
\end{abstract}

\section{Keywords}

Preschool Education, Social Competence, Temperament

\section{Introduction}

For many children, preschool period represents the opportunity to interact with many peers in the first social arena outside their family, establish positive relationships with teachers, and develop social skills (i.e. ability to cooperate and establish empathy) (Baumgartner \& Strayer, 2008; Coplan \& Armer, 2008; Denham et al., 2009; Martin et al., 2005; O’Connor, 2010; Rubin \& Coplan, 2004). The critical aspects of social-emotional development throughout the preschool period include children's ability to build positive social ties with adults and their peers, understand other people's feelings, control their own feelings and behaviors, and regulate their feelings (Denham et al., 2003; Izard et al., 2001). Therefore, it is very important for early childhood educators to assess and support children's socio-emotional development (Dunsmore, Noguchi, Garner, Casey, \& Bhullar, 2008; 
Öneren-Şendil, 2010). In this context, social competence was found to have a significant impact on development of a child's social interactions in the future (Fabes et al., 2006; Rubin et al., 2006).

Social competence during early childhood is defined as children's success in being involved in social interactions, achieving socials goals, establishing and maintaining friendships, and getting accepted by peers (BrophyHerb, Lee, Nievar, \& Stollak, 2007; Chen \& French, 2008; Rubin, Bukowski, \& Parker, 2006). Katz and McClellan (1991) represent that social competence generally involves the ability to start communication and mutually maintain one's relationships with his/her peers in a satisfying manner. Social competence often refers to the ease and effectiveness of a child's interactions with others. Social competence development is considered one of the milestones of development (Thomas \& Chess, 1980). Kerr and Nelson (1989) stated that an individual's social competence develops with positive feedback received by him/her from the environment as a result of him/her displaying his/her social skills in appropriate places or environments at appropriate time. Gresham and Reschly (1987) describe social competence in two dimensions, including adaptive behavior and social skills. Adaptive behaviors consist of independent functioning skills, physical development, academic competences, and language development of children and young people. Social skills are comprised of three sub-dimensions. These dimensions are interpersonal behaviors, self-related behaviors and task-related behaviors. Interpersonal behaviors cover accepting authority, speaking skills, cooperative behaviors and play behaviors; self-related behaviors cover expressing one's own feelings, ethical behavior, adopting positive attitudes toward one's own self, and task-related behaviors cover paying attention to warnings, fulfilling one's responsibilities, following instructions/directions, and working independently (Gresham, 1988). Gresham (1986) added a third sub-dimension called "peer acceptance" to social competence. Peer acceptance is both a part of social competence and an outcome of adequate social behaviors. Children gain peer-based social competence during the preschool period. If children encounter problems or failures in their peer relationships in this period, this will pose a risk for them in the future in terms of behavior and social maladjustment (Brown, Odom, \& Conroy, 2001). If children show more positive interactions and more collaborative plays in comparison to their aggressive or introverted peers, they are accepted more by their peers (Sette, 2012). Displaying aggressive behaviors may further lead to the ruin of peer relationships (Merrell et al., 2001).

In addition to social skills and peer relationships, children's temperament was also indicated to have an impact on children's social competence (Rubin et al., 2006; Sanson et al., 2002). Acting as a bridge between a child's home environment and his/her social world, temperament is a structure which could influence social relationships (Szewczyk-Sokolowski, Bost, \& Wainwrigjht, 2005). Sanson, Hemphill and Smart (2002) defined temperament as individual differences in ones' behavioral styles, that are evident from early childhood years. Temperament refers to individual differences in reactivity and self-regulation (Rothbart \& Bates, 1998). Thomas et al. (1963) suggested that temperament consists of nine dimensions, including approach-withdrawal, adaptability, quality of mood, intensity of reaction, distractibility, persistence/attention span, rhythmicity, threshold of responsiveness, and activity level. Approach-withdrawal refers to the response to a new object or person. Adaptability, refers to the child either adjusts to changes in routines or plans easily or resists transitions. Quality of mood, refers to the amount of pleasant and cheerful behavior (positive mood), as contrasted with fussy, sad and unpleasant behavior (negative mood). Intensity of reaction refers to the energy level of a response whether positive or negative. Distractibility, the child is either easily distracted from what he is doing or shuts out external distractions and stays with the current activity. Persistence/attention span refers to the length of time a child's continues in activities in the face of obstacles. Rhythmicity refers to the regularity of child's sleep, wakefulness, eating, and elimination. Threshold of responsiveness refers to the child's reaction to a range of external stimuli or environmental changes. Activity level refers to the child's physical energy. Researchers have found that children can be categorized into three temperament groups based on these individual differences: easy, difficult, and slow-to-warm-up (Chess \& Thomas, 1996; Thomas \& Chess, 1977; Thomas, Chess, \& Birch, 1968).

Temperament is an important element for preschool children in terms of peer acceptance and social competence (Eisenberg et al., 2003). Temperament in childhood is regarded as a basic feature which influences personality, emotionality and social behaviors (Berdan, Keane, \& Calkins, 2008; David \& Murphy, 2007; Rothbart, Ahadi, \& Evans, 2000; Sterry et al., 2010). Various aspects of temperament such as sociability, inhibition, effortful-control, activity level, and negative emotionality all act to influence social competence (Bohlin, Hagekull, \& Andersson, 2005; Çorapç1, 2008; Diener \& Kim, 2004; Mendez et al., 2002). Temperamental dimensions may contribute differently to different aspects of social competence (Rubin et al., 2006). It is possible for children who display high level of emotionality to show antisocial behaviors or behaviors such as aggression, fight or 
possessiveness (Rubin, Burgess, Dwyer, \& Hastings, 2003). Similarly, children who used to be shy or introverted from preschool to primary school period are likely to be less prosocial than their more sociable peers (Eisenberg, Shepard, Fabes, Murphy, \& Guthrie, 1998; Rydell, Bohlin, \& Thorell, 2005). Wichmann, Coplan, and Daniels (2004) discovered that socially introverted children exhibit lower level of social competence than their non-introverted peers.

Recent research showed that children who could not develop any social competence skills during the first six years of their lives are more likely to exhibit emotional and behavioral problems and become a socially incompatible person in adulthood (Ladd, 2000). Researchers have also investigated the role of temperamental traits in predicting child's social competence. For example, the relationship between children exhibiting inhibited temperamental traits and social competence has been shown repeatedly, with inhibited children displaying higher levels of shy behaviors and lower levels of social competence (Fox et al., 1995; Rubin, Burgess, Dwyer, \& Hastings, 2003). In line with the aforementioned statements, it is of great importance in terms of supporting and improving children's social competence skills at an earlier period that the effects of temperament on children's social competence are revealed. Further to this, no study has been found which deals with the temperament features and social competence that often surface during the preschool period in Turkey. The current study is an original study in Turkey. Therefore, this study was designed to investigate the relationship between preschool children's temperament and social competence. Answers to the following questions have been sought:

1) Is there a relationship between preschool children's social competence and temperament traits (approach/ withdrawal, persistence, rhythmicity and reactivity dimensions)?

2) Do temperament trait variables have a predictive effect for the social competence dimensions of children?

\section{Methodology}

\subsection{Participants}

The present study was conducted in the city of Uşak, in Turkey. The participants in the present study consisted of 112 children between the ages of $5-6$, all enrolled in one of five public preschools in Uşak, Turkey. There were 57 boys and 55 girls, from middle or middle-high socio-economic status (SES) families. The average age of the children was five years, six months. The sample group for the study was selected using a random sampling method. The sampling method was applied by drawing lots among the names of kindergartens in the city center of Uşak, resulting in five schools being accepted for participation in the study. Schools were gotten contact with in accordance with the permissions obtained from the Provincial National Education Directorates of Uşak.

\subsection{Measures}

In order to measure temperamental characteristics of the children in the sample, their mothers completed the Turkish version (Yağmurlu \& Sanson, 2009) of the Short Temperament Scale for Children (STSC) (Prior, Sanson, \& Oberklaid, 1989). The mothers evaluated their children's temperamental characteristics on a basis of a Likert-type scale, with six frequency choices. The scale consists of 30 items with four subscales, which measured approach/withdrawal, persistence, rhythmicity and reactivity dimensions. Sample items for dimensions were: Approach/withdrawal (e.g. "My child is shy when first meeting new children"); Persistence (e.g. "My child is unwilling to leave a game or activity that he/she has not completed"); Reactivity ( e.g. "If my child resists some activity such as having hair brushed, he/she will continue to resist it for months"); and Rhythmicity (e.g. "After my child is put to bed at night, he/she takes about the same length of time to fall asleep"). The scale has proved to be a reliable form of measurement, with an average Cronbach Alpha of .70 for the reactivity subscale; .50 for the approach/withdrawal subscale; .66 for the persistence subscale; and .60 for the rhythmicity subscale.

The Social Competence and Behavior Evaluation Scale, short form (SCBE-30): (LaFreniere \& Dumas, 1996). This 30-item scale for children in the $30-78$ months age range is composed of three subscales; two distinct patterns of maladaptive behavior (the Anger-Aggression or AA and Anxiety-Withdrawal, or AW subscales) and one adaptive pattern (the Social Competence, or SC, subscale). The scale was completed by the children's teacher. The AA subscale reflects children's angry, aggressive, and irritable behaviors. Children were evaluated as angry and aggressive who showed negative affects and was unable to regulate their negative emotions. The AW sub- 
scale is composed of items that measure dependent, anxious, and isolated behaviors. These children spend much of their time alone and unoccupied and demonstrate little interest in group activities. Finally, the SC subscale includes items used to assess positive social interaction (e.g., can negotiate solutions, works easily in groups) as well as prosocial behavior/empathy toward their peers at school (e.g., cooperates, shares toys, comforts others). Socially competent children show positive affect in their interactions and are well appreciated by their peers and teachers. Responses were given on a 6-point Likert scale from 1 (never) to 6 (always). Çorapçı, Aksan, ArslanYalçın and Yağmurlu adapted the scale into Turkish in 2010. The Cronbach's alpha value averages for the originnal version of the scale were .87 for the SC, .84 for the AW, and .88 for the AA respectively (LaFreniere et al., 2002). The Cronbach's alpha for the current study were .86 for the SC and .90 for the AA.

\subsection{Procedure}

First of all necessary documents related to this study were prepared and given to the Ministry of Education to obtain permission to collect the data in schools. The selected schools were visited in order to inform teachers about the study and measurement. Data on children's social competence was collected from their teachers. The STSC in this study was completed by the mothers of children. Permission was obtained from parents prior to initiating the study. The mothers and teachers were informed about the objectives of the research and the measurement tools prior to the data collection process. Teachers filled in the forms in parallel with their general observations of the children for a period of approximately seven months.

\subsection{Data Analysis}

Data on the printed instruments was recorded on a personal computer. SPSS version 20.0 was used to analyze the data. The Pearson Product-Moment Correlation Coefficient and multiple regression analysis were used to analyze the data. The Pearson Product-Moment Correlation Coefficient technique was used to reveal the relationship between social competence and temperament dimensions. A multiple regression method was used to determine the social competence of children possessing the various temperament traits.

\section{Results}

Correlation coefficients were computed to examine associations among teachers' reports of child social competence, as well as mothers' reports of child temperament.

As seen in Table 1, social competence was positively related to persistence and rhythmicity, although social competence was unrelated to either the approach/withdrawal or reactivity dimensions. However, anger/aggression was positively correlated with reactivity.

Table 2 shows that persistence $(p<0.01)$ and rhythmicity $(p<0.01)$, were significant predictors of social competence for children. The results indicate that the selected variables all together predict $27 \%$ of social competence.

Table 3 illustrates that the multiple regression analyses were significant $(p<0.01)$. As demonstrated by the results, the variables of approach/withdrawal and reactivity temperament dimensions reveal a positive significant relationship with social competence.

Table 1. The means, standard deviations and correlation coefficients of the variables in this study.

\begin{tabular}{cccccccc}
\hline Variables & Means \pm SD & 1 & 2 & 3 & 4 & 5 & 6 \\
\hline 1) Social Competence & $31.65 \pm 8.86$ & -- & $-.23^{*}$ & .16 & $.43^{* *}$ & $.24^{*}$ & -.08 \\
2) Anger-Aggression & $22.58 \pm 10.60$ & & -- & .16 & .03 & .02 & $.70^{* *}$ \\
3) Approach/withdrawal & $27.39 \pm 3.79$ & & -- & .08 & -.04 & .06 \\
4) Persistence & $29.36 \pm 5.68$ & & -- & .02 & .03 \\
5) Rhythmicity & $25.77 \pm 3.67$ & & & -- & .11 \\
6) Reactivity & $26.55 \pm 7.32$ & & & & -- \\
\hline
\end{tabular}

Note: $\mathrm{N}=112 ;{ }^{*} p<.05,{ }^{* *} p<.01$. 
Table 2. Results of the multiple regression analysis for predicting social competence.

\begin{tabular}{ccccc}
\hline & $\mathrm{B}$ & $\beta$ & $\mathrm{t}$ & $p$ \\
\hline Approach/withdrawal & .28 & .12 & 1.463 & .15 \\
Persistence & .66 & .42 & 5.077 & $.00^{* *}$ \\
Rhythmicity & .60 & .25 & 3.005 & $.00^{* *}$ \\
Reactivity & -.15 & -.12 & -1.481 & .14 \\
$\mathrm{R}=.52 \quad \mathrm{R}^{2}=.27^{* *}$ & & & & \\
$\mathrm{~F}(4,111)=10.009$ & & & & \\
\hline
\end{tabular}

Note: $\mathrm{N}=112 ;{ }^{* *} p<.01$.

Table 3. Results of the multiple regression analysis for predicting anger/aggression.

\begin{tabular}{ccccc}
\hline & $\mathrm{B}$ & $\beta$ & $\mathrm{t}$ & $p$ \\
\hline Approach/withdrawal & .58 & .20 & 3.176 & $.00^{* *}$ \\
Persistence & -.02 & -.01 & -.179 & .85 \\
Rhythmicity & -.12 & -.04 & -.672 & .070 \\
Reactivity & 1.05 & .0911 & $.00^{* *}$ \\
$\mathrm{R}=.74 \quad \mathrm{R}^{2}=.55^{* *}$ & & & & \\
$\mathrm{~F}(4,111)=32.291$ & & & & \\
\hline
\end{tabular}

Note: $\mathrm{N}=112 ;{ }^{* *} p<.01$.

\section{Discussion}

The results of this study are consistent with the idea that there is a significant relationship between some of children's temperamental dimensions and their social competences. According to the results of Pearson Product Moment Correlation Coefficient Technique, the persistence and rhythmicity sub-scales of the children's temperament levels have a significant positive relationship to social competence. On the other hand a high level of positively significant relationship was found between anger/aggression and reactivity temperament sub-scales. Another result obtained from the study is that children's temperament traits have a predictor effect on child social competence. According to the results of the study, persistence and rhythmicity temperament sub-scales were significant predictors of social competence for children. The results of this study concluded that the reactivity and approach/withdrawal temperament dimensions had a significant predictive effect on the anger/aggression.

The studies conducted on the subject also show parallel with the finding obtained from the present study. Temperament has been recognized as an important factor in social competence among preschool children, including behavior around peers and peer acceptance (Sterry et al., 2010). A child's temperamental features play a critical role on development of social competence and other social behaviors in children. For instance, temperamental features may have a significant influence on supporting or hindering social competence behaviors (Fabes et al., 2006). It is argued that the child's temperament is in a way correlated with the problems he/she is to encounter in his/her social relations (Denham et al., 2003; Moon, 2001). Walker, Berthelson, and Irving (2001) have ascertained within the scope of their research that children who are not socially accepted have more problematic temperamental characteristics compared to those of popular children. In a study conducted on 42 children of 5 - 6 years of age, Öneren-Şendil (2010) investigated the relationship between sex, peer choices and temperamental features. As a result of the research, it was revealed that children with high level of persistence and approach possess high level of social competence, while those with high level of reactivity experience anger/aggression behavior problem more.

The results of this study concluded that the reactivity and approach/withdrawal temperament dimensions had a significant predictive effect on the anger/aggression. Anger-Aggression (AA) subscale measures externalization problem indicators, including defiance against adults, displaying incompatible and aggressive behaviors in 
peer relationships. Olweus (1984) focused on emotional problems related to social competence such as aggression and anger and identified a correlation between temperament and aggression. In a longitudinal study by Eisenberg et al., children with high level of approach/withdrawal scores were found to have low level of self-control and aggression (Eisenberg et al., 1998). Howes and Phillipsen (1998) observed children in various environments for 9 years. As a result of the study, they determined that children who have played with their peers and acquired social skills during infancy displayed less aggressive and less introverted behaviors in later stages of their lives. Lower social competence is associated with a temperament quality of high reactivity (Rothbart, 2007; Rothbart, 2011). Children with higher temperamental reactivity and emotional regulation capacity are characterized as extroverted, sociable, and boundless, and on the contrary, those with higher emotional regulation capacity but with lower reactivity are characterized as non-extroverted and highly-controlled (Nolen-Morse, 2013). In a study by Çorapçı (2008), children who obtained a low score from temperamental dimension of impulsivity were found to have high social competence. Sokhey and Sokhey (2010) conducted a study to identify the role of temperament on children's social competences. As a result of the research, temperamental dimension of approach-withdrawal was demonstrated to correlate with social competence. In another study, Rydell et al. (2005) discovered that preschool children having temperamental feature of approach are more withdrawn than their sociable peers in starting social interactions with their peers. These results indicate that temperamental reactivity and approachwithdrawal sub-dimensions interact in important ways to influence a child's social competence.

In preschool period, socially competent children are expected to build stronger emotional ties with their parents, have self-confidence, be accepted to play group by peers, have positive relationships with peers and other adults, cooperate, and have friends with whom they'll be involved in activities (Thompson \& Happold, 2002; Verschueren, Buyck, \& Marcoen, 2001). Previous research revealed that children with relatively high social competence are those accepted by their peers (Blandon et al., 2010; Spinrad et al., 2004; Spivack \& Howes, 2011), having more positive emotions about school, and displaying high level of participation at school (Ladd, Kochenderfer, \& Coleman, 1996; Thompson \& Happold, 2002). Gleason et al. (2005) emphasized that some temperamental dimensions are influential on the development of friendship in preschool children. Conversely, children who are unsuccessful in their social relationships may pose serious risks in terms of social nonconformity in time (Buhs et al., 2006; Denham et al., 2009; Ladd, 2006). Socially incompetent children show more behavioral problems, peer rejection, and lower school success than those with adequate social competence (Bierman, 2004; Chen \& Jiang, 2002; Malti, 2006). Conclusions from various researches have shown that lower social competence leads the way to such negative outcomes as troubled peer relations, loneliness and peer rejection, internalization and externalization (Bierman, 2004; Burt, Obradovic, Long, \& Masten, 2008; Bush \& Ladd, 2001; Ladd, 2006; Ladd \& Troop-Gordon, 2003; Parker \& Asher, 1987).

Preschool children's social competences have a lasting impact on peer acceptance (Johnson, Ironsmith, Snow, \& Poteat, 2000). In a study conducted by Mendez, Fantuzzo and Cicchetti (2002), the correlation between personality characteristics of Afro-American children attending Head Start program and peer play competence was investigated. Children's social competence was examined in terms of interactive competence and direct aggression. Children with interactive competence were found to possess positive temperamental features, and displayed successful peer play interactions. Children who displayed direct aggression spoiled peer plays, and did not share their toys with others. In a study by Lewis (1988), the correlation between preschool children's peer acceptance and coping skills were investigated within the scope of social skills. Ten children with developmental incompetence and four children without developmental incompetence were included in the study. Children's peer acceptance and coping skills were monitored for 6 months. The children who were successful in coping were found to get high scores from social competence test. It was also concluded that coping skills enhanced peer acceptance (cited by Ummanel, 2007). In a study by Flanagan (1994), a social skill education program in accordance with the results of the teacher's form of "Social Skill Rating System" was applied to a total of 51 kindergarten students of African, American, and Spanish origin either under risk or free from risk in terms of social competence. When the program was completed, it was evident that social skill scores of both groups increased; there was a significant correlation between development of social skills and academic achievement, and academic achievement increased.

\section{Conclusion}

Acquiring social competence skills in early childhood increase children's success in social environments outside home. More importantly, developing social competence in preschool children may reduce the likelihood of these 
children showing emotional/behavioral adaptation (such as internalization and externalization problems) (Rubin, Bukowski, \& Parker, 2006; Sanson, Hemphill, \& Smart, 2004).

This study had some limitations. First, in the current study, the sample size $(\mathrm{N}=112)$ was too small. Future research should be considered larger samples to utilize. Secondly, a longitudinal study could be conducted in the future. Third, futures studies can be planned to investigate the various effects of the other variables have on children's social competence. For example, examination of additional child characteristics, namely intelligence, would have made for a stronger study. In addition, the current study is that children's social competencies were assessed by the same teacher. Consequently, there is an evident need for future studies in which children's social competence is examined by independent raters, such as observers, parents, or peers.

\section{References}

Baumgartner, E., \& Strayer, F. F. (2008). Beyond Flight or Fight: Developmental Changes in Young Children's Coping with Peer Conflict. Acta Ethologica, 11, 16-25. http://dx.doi.org/10.1007/s10211-007-0037-7

Berdan, L. E., Keane, S. P., \& Calkins, S. D. (2008). Temperament and Externalizing Behavior: Social Prefence and Percieved Acceptance as Protective Factors. Developmental Psychology, 44, 957-968. http://dx.doi.org/10.1037/0012-1649.44.4.957

Bierman, K. L. (2004). Peer Rejection: Developmental Processes and Intervention Strategies. New York: Guilford.

Blandon, A. Y., Calkins, S. D., Grimm, K. J., Keane, S. P., \& O’Brien, M. (2010). Testing a Developmental Cascade Model of Emotional and Social Competence and Early Peer Acceptance. Development and Psychopathology, 22, 737-748. http://dx.doi.org/10.1017/S0954579410000428

Bohlin, G., Hagekull, B., \& Andersson, K. (2005). Behavioral Inhibition as a Precursor of Peer Social Competence in Early School Age: The Interplay with Attachment and Nonparental Care. Merrill-Palmer Quarterly, 51, 1-19. http://dx.doi.org/10.1353/mpq.2005.0001

Brophy-Herb, H., Lee, R. E., Nievar, M. A., \& Stollak, G. (2007). Preschoolers' Social Competence: Relations to Family Characteristics, Teacher Behaviors and Classroom Climate. Journal of Applied Developmental Psychology, 28, 134-148. http://dx.doi.org/10.1016/j.appdev.2006.12.004

Brown, W. H., Odom, S. L., \& Conroy, M. (2001). An Intervention Hierarchy for Promoting Preschool Children's Peer Interactions in Naturalistic Environments. Topics in Early Childhood Special Education, 21, 162-175. http://dx.doi.org/10.1177/027112140102100304

Burt, K. B., Obradović, J., Long, J. D., \& Masten, A. S. (2008). The Interplay of Social Competence and Psychopathology over 20 Years: Testing Transactional and Cascade Models. Child Development, 79, 359-374. http://dx.doi.org/10.1111/j.1467-8624.2007.01130.x

Bush, E. S., \& Ladd, G. W. (2001). Peer Rejection as an Antecedent of Young Children's School Adjustment: An Examination of Mediating Processes. Developmental Psychology, 37, 550-560. http://dx.doi.org/10.1037/0012-1649.37.4.550

Buhs, E. S., Ladd, G. W., \& Herald, S. L. (2006). Peer Exclusion and Victimization: Processes That Mediate the Relation between Peer Group Rejection and Children's Classroom Engagement and Achievement? Journal of Educational Psychology, 98, 1-13. http://dx.doi.org/10.1037/0022-0663.98.1.1

Chen, Q., \& Jiang, Y. (2002). Social Competence and Behavior Problems in Chinese Preschoolers. Early Education \& Development, 13, 171-186. http://dx.doi.org/10.1207/s15566935eed1302 4

Chen, X., \& French, D. C. (2008). Children's Social Competence in Cultural Context. Annual Review of Psychology, 59, 591-616. http://dx.doi.org/10.1146/annurev.psych.59.103006.093606

Chess, S., \& Thomas, A. (1996). Temperament: Theory and Practice. NY: Brunner/Mazel.

Coplan, R. J., \& Arbeau, K. A. (2008). The Stresses of a "Brave New World": Shyness and School Adjustment in Kindergarten. Journal of Research in Childhood Education, 22, 377-389. http://dx.doi.org/10.1080/02568540809594634

Çorapçı, F. (2008). The Role of Child Temperament on Head Start Preschoolers' Social Competence in the Context of Cumulative Risk. Journal of Applied Developmental Psychology, 29, 1-16. http://dx.doi.org/10.1016/j.appdev.2007.10.003

Çorapçı, F., Aksan, N., Arslan-Yalçın, D., \& Yağmurlu, B. (2010). Okul öncesi dönemde duygusal, davranışsal ve sosyal uyum taraması: Sosyal yetkinlik ve davranış değerlendirme-30 ölçeği. Çocuk ve Gençlik Ruh Sağll̆̆g Dergisi, 17, 63-74. (1n Turkish)

David, K. M., \& Murphy, B. C. (2007). Interparental Conflict and Preschooler's Peer Relations: The Moderating Roles of Temperament and Gender. Social Development, 16, 1-23. http://dx.doi.org/10.1111/j.1467-9507.2007.00369.x

Denham, S. A., Blair, K. A., DeMulder, E., Levitas, J., Sawyer, K., Auerbach-Major, S., \& Queenan, P. (2003). Preschool 
Emotional Competence: Pathway to Social Competence? Child Development, 74, 238-256. http://dx.doi.org/10.1111/1467-8624.00533

Denham, S. A., Wyatt, T. M., Bassett, H. H., Echeverria, D., \& Knox, S. S. (2009). Assessing Social-Emotional Development in Children from a Longitudinal Perspective. Journal of Epidemiology and Community Health, 63, 37-52.

Diener, M. L., \& Kim, D. Y. (2004). Maternal and Child Predictors of Preschool Children's Social Competence. Journal of Applied Developmental Psychology, 25, 3-24. http://dx.doi.org/10.1016/j.appdev.2003.11.006

Dunsmore, J. C., Ryoichi, J. P., Noguchi, R. J. P., Garner, P. W., Casey, E. C., \& Bhullar, N. (2008). Gender-Specific Linkages of Affective Social Competence with Peer Relations in Preschool Children. Early Education and Development, 19, 211-237. http://dx.doi.org/10.1080/10409280801963897

Eisenberg, N., Shepard, S. A., Fabes, R. A., Murphy, B. C., \& Guthrie, I. K. (1998). Shyness and Children's Emotionality, Regulation, and Coping: Contemporaneous, Longitudinal, and Across-Context Relations. Child Development, 69, 767790 .

Eisenberg, N., Valiente, C., Fabes, R. A., Smith, C. L., Reiser, M., Shepard, S. A., Losoya, S. H., Guthrie, I. K., Murphy, B. C., \& Cumberland, A. J. (2003). The Relations of Effortful Control and Ego Control to Children's Resiliency and Social Functioning. Developmental Psychology, 39, 761-776.

Fabes, R. A., Gaertner, B. M., \& Popp, T. K. (2006). Getting along with Others: Social Competence in Early Childhood. In K. McCartney, \& D. Phillips (Eds.), Blackwell Handbook of Early Childhood Development (pp. 297-316). Malden, MA: Blackwell Publishing.

Flanagan, D. P. (1994). The Effectiveness of a Social Skills Intervention with Minority Kindergarten Students. http://www.vincenter.org

Fox, N. A., Rubin, K. H., Calkins, S. D., Marshall, T. R., Coplan, R. J., Porges, S. W., Long, J., \& Stewart, S. L. (1995). Frontal Activation Asymmetry and Social Competence at Four Years of Age: Left Frontal Hyper and Hypo-Activation as Correlates of Social Behavior in Preschool Children. Child Development, 66, 1770-1784. http://dx.doi.org/10.2307/1131909

Gleason, T. R., Gower, A. L., Hohmann, L. M., \& Gleason, T. C. (2005). Temperament and Friendship in Preschool-Aged Children. International Journal of Behavioral Development, 29, 336-344.

Gresham, F. M. (1986). Conceptual and Definitional Issues in the Assessment of Children's Social Skills: Implications for Classification and Training. Journal of Clinical Child Psychology, 15, 3-15. http://dx.doi.org/10.1207/s15374424jecp1501_1

Gresham, F. M., \& Reschly, D. J. (1987). Dimensions of Social Competence: Method Factors in the Assessment of Adaptive Behavior, Social Skills, and Peer Acceptance. Journal of School Psychology, 25, 367-381. http://dx.doi.org/10.1016/0022-4405(87)90038-0

Gresham, F. M. (1988). Social Skills: Conceptual and Applied Aspects of Assessment, Training, and Social Validation. In J. C. Witts, S. N. Elliot, \& Gresham, F. M. (Eds.), Handbook of Behaviour Therapy in Education (pp. 523-546). New York: Plenum Press. http://dx.doi.org/10.1007/978-1-4613-0905-5_20

Howes, C., \& Phillipsen, L. (1998). Continuity in Children's Relationships with Peers. Social Development, 7, $340-349$. http://dx.doi.org/10.1111/1467-9507.00071

Izard, C. E., Fine, S., Schultz, D., Mostow, A. J., Ackerman, B., \& Youngstrom, E. (2001). Emotion Knowledge as a Predictor of Social Behavior and Academic Competence in Children at Risk. Psychological Science, 12, 18-23.

Johnson, C., Ironsmith, M., Snow, C. W., \& Poteat, G. M. (2000). Peer Acceptance and Social Adjustment in Preschool and Kindergarten. Early Childhood Education Journal, 27, 207-212. http://dx.doi.org/10.1023/B:ECEJ.0000003356.30481.7a

Katz, L. G., \& McClellan, D. (1991). The Teacher's Role in the Social Development of Young Children. Urbana, IL: ERIC Clearinghouse on Elementary and Early Childhood Education, 1991. ED 331642.

Kerr, M. M., \& Nelson, C. M. (1989). Strategies for Managing Behavior Problems in the Classroom (2nd ed.). Columbus, $\mathrm{OH}:$ Merrill.

Ladd, G. W., Kochenderfer, B. J., \& Coleman, C. C. (1996). Friendship Quality as a Predictor of Young Children's Early School Adjustment. Child Development, 67, 1103-1118.

Ladd, G. W. (2000). The Fourth R: Relationships as Risks and Resources Following Children's Transition to School. American Educational Research Association Division E Newsletter, 19, 9-11.

Ladd, G. W., \& Troop-Gordon, W. (2003). The Role of Chronic Peer Difficulties in the Development of Children's Psychological Adjustment Problems. Child Development, 74, 1344-1367. http://dx.doi.org/10.1111/1467-8624.00611

Ladd, G. W. (2006). Peer Rejection, Aggressive or Withdrawn Behavior, and Psychological Maladjustment from Ages 5 to 12: An Examination of Four Predictive Models. Child Development, 77, 822-846. http://dx.doi.org/10.1111/j.1467-8624.2006.00905.x 
LaFreniere, P. J., \& Dumas, J. E. (1996). Social Competence and Behavior Evaluation in Children Ages 3 to 6 Years: The Short Form (SCBE-30). Psychological Assessment, 8, 369-377. http://dx.doi.org/10.1037/1040-3590.8.4.369

LaFreniere, P. J., Masataka, N., Butovskaya, M., Chen, Q., Dessen, M. A., Atwanger, K., Schreiner, S., Montirosso, R., \& Frigerio, A. (2002). Cross-Cultural Analysis of Social Competence and Behavior Problems in Preschoolers. Early Education \& Development, 13, 201-219. http://dx.doi.org/10.1207/s15566935eed1302 6

Lewis, G. F. (1988). The Social Competence of Preschool Children's Response to Conflict and Peer Acceptance in a Mainstreamed Classroom. Doctoral Theses, Urbana-Champain: University of Illinois at Urbana-Champain.

Malti, T. (2006). Aggression, Self-Understanding, and Social Competence in Swiss Elementary-School Children. Swiss Journal of Psychology, 65, 81-91. http://dx.doi.org/10.1024/1421-0185.65.2.81

Martin, C. L., Fabes, R. A., Hanish, L. D., \& Hollenstein, T. (2005). Social Dynamics in the Preschool. Developmental Review, 25, 299-327. http://dx.doi.org/10.1016/j.dr.2005.10.001

Mendez, J., McDermott, P., \& Fantuzzo, J. (2002). Identifying and Promoting Social Competence with African-American Preschool Children: Developmental and Contextual Considerations. Psychology in the Schools, 39, 111-123. http://dx.doi.org/10.1002/pits.10039

Mendez, J. L., Fantuzzo, J., \& Cicchetti, D. (2002). Profiles of Social Competence among Low-Income African American Preschool Children. Child Development, 73, 1085-1100. http://dx.doi.org/10.1111/1467-8624.00459

Merrell, K. W., Streeter, A. L., Boelter, E. W., Caldarella, P., \& Gentry, A. (2001). Validity of the Home and Community Social Behavior Scales: Comparisons with Five Behavior-Rating Scales. Psychology in the Schools, 38, 313-325. http://dx.doi.org/10.1002/pits.1021

Moon, M. (2001). Teacher Perspectives on Peer Relation Problems of Young Children. Asia Pacific Education Review, 2 , 22-31. http://dx.doi.org/10.1007/BF03024929

Nolen-Morse, J. M. (2013). Temperamental Reactivity and Children's Social Competence. Unpublished Mater Thesis, Oregon State University, Corvallis.

O’Connor, E. (2010). Teacher-Child Relationships as Dynamic Systems. Journal of School Psychology, 48, 187-218. http://dx.doi.org/10.1016/j.jsp.2010.01.001

Olweus, D. (1984). Aggressors and Their Victims: Bullying at School. In N. Frude, \& H. Gault (Eds.), Disruptive Behavior in Schools (pp. 57-76). New York: Wiley.

Öneren-Şendil, C. (2010). An Investigation of Social Competence and Behavioral Problems of 5 - 6 Years Old Children through Peer Preference, Temperament and Gender. Unpublished Master Thesis, Ankara: Middle East Technical University.

Parker, J. G., \& Asher, S. R. (1987). Peer Relations and Later Personal Adjustment: Are Low-Accepted Children at Risk? Psychological Bulletin, 102, 357-389. http://dx.doi.org/10.1037/0033-2909.102.3.357

Prior, M., Sanson, A., \& Oberklaid, F. (1989). The Australian Temperament Project. In G. Kohnstamm, J. Bates, \& M. Rothbart (Eds.), Temperament in Childhood (pp. 537-556). New York: John Wiley.

Rothbart, M., \& Bates, J. (1998). Temperament. In W. Damon (Series Ed.), \& N. Eisenberg (Vol. Ed.), Handbook of Child Psychology: Vol. 3. Social, Emotional, and Personality Development (5th ed., pp. 105-176). New York: Wiley.

Rothbart, M. K., Ahadi, S. A., \& Evans, D. E. (2000). Temperament and Personality: Origins and Outcomes. Journal of Personality \& Social Psychology, 78, 122-135. http://dx.doi.org/10.1037/0022-3514.78.1.122

Rothbart, M. K. (2007). Temperament, Development, and Personality. Current Directions in Psychological Science, 16, $207-$ 212. http://dx.doi.org/10.1111/j.1467-8721.2007.00505.x

Rothbart, M. K. (2011). Becoming Who We Are: Temperament and Personality in Development. New York: The Guilford Press.

Rubin, K. H., Burgess, K. B., Dwyer, K. M., \& Hastings, P. D. (2003). Predicting Preschoolers' Externalizing Behaviors from Toddler Temperament, Conflict, and Maternal Negativity. Developmental Psychology, 39, 164-176.

http://dx.doi.org/10.1037/0012-1649.39.1.164

Rubin, K. H., \& Coplan, R. J. (2004). Paying Attention to and Not Neglecting Social Withdrawal and Social Isolation. Merrill-Palmer Quarterly, 50, 506-534. http://dx.doi.org/10.1353/mpq.2004.0036

Rubin, K. H., Bukowski, W. M., \& Parker, J. G. (2006). Peer Interactions, Relationships, and Groups. In W. Damon, R. M. Lerner (Series Eds.), \& N. Eisenberg (Vol. Ed.), Handbook of Child Psychology: Vol. 3. Social, Emotional, and Personality Development (6th ed., pp. 571-645). Hoboken, NJ: Wiley.

Rydell, A. M., Bohlin, G., \& Thorell, L. B. (2005). Representations of Attachment to Parents and Shyness as Predictors of Children's Relationships with Teachers and Peer Competence in Preschool. Attachment and Human Development, 7, 187204. http://dx.doi.org/10.1080/14616730500134282 
Sanson, A., Hemphill, A. S., \& Smart, D. (2002). Temperament and Social Development. In Smith, P. K., \& Hart, C. H. (Eds.), Blackwell Handbook of Childhood Social Development (pp. 97-116). Oxford: Blackwell Publishers.

Sanson, A., Hemphill, S. A., \& Smart, D. (2004). Connections between Temperament and Social Development: A Review. Social Development, 13, 142-170. http://dx.doi.org/10.1046/j.1467-9507.2004.00261.x

Sette, S. (2012). The Social Adjustment in Preschool Age. The Role of Socio-Emotional Competence and Teacher-Child Relationship Quality on Peer Acceptance. Doctoral Thesis, Rome: Sapienza Universita di Roma.

Sokhey, S., \& Sokhey, G. (2010). Temperament and Social Competence amongst Children: Implications for Well-Being. Journal of Indian Health Psychology, 4, 1-18.

Spinrad, T. L., Stifter, C. A., Donelan-McCall, N., \& Turner, L. (2004). Mothers' Regulation Strategies in Response to Toddlers' Affect: Links to Later Emotion Self-Regulation. Social Development, 13, 40-55. http://dx.doi.org/10.1111/j.1467-9507.2004.00256.x

Spivack, A. L., \& Howes, C. (2011). Social and Relational Factors in Early Education and Prosocial Actions of Children of Diverse Ethnocultural Communities. Merrill-Palmer Quarterly, 57, 1-24.

Sterry, T. W., Reiter-Purtill, J., Gartstein, M. A., Gerhardt, C. A., Vannatta, K., \& Noll, R. B. (2010). Temperament and Peer Acceptance: The Mediating Role of Social Behavior. Merrill-Palmer Quarterly, 56, 189-219. http://dx.doi.org/10.1353/mpq.0.0047

Szewczyk-Sokolowsky, M., Bost, K. K., \& Wainwright, A. B. (2005). Attachment, Temperament and Preschool Children's Peer Acceptance. Social Development, 14, 379-397. http://dx.doi.org/10.1111/j.1467-9507.2005.00307.x

Thomas, A., Chess, S., Birch, H. G., Hertzig, M. E., \& Korn, S. (1963). Behavioural Individuality in Early Childhood. New York: New York University Press.

Thomas, A., Chess, S., \& Birch, H. G. (1968). Temperament and Behavior Disorders in Children. New York: New York University Press.

Thomas, A., \& Chess, S. (1977). Temperament and Development. New York: Bruner/Mazel.

Thomas, A., \& Chess, S. (1980). The Dynamics of Psychological Development. New York: Bruner/Mazel.

Thompson, R., \& Happold, C. (2002). The Roots of School Readiness in Social and Emotional Development. The Kauffman Early Education Exchange, 1, 8-29.

Ummanel, A. (2007). Okul öncesi çocuklarda akran kabulünün çeşitli değişkenler açısından incelenmesi. Unpublished Master Thesis, Ankara. (in Turkish)

Verschueren, K., Buyck, P., \& Marcoen, A. (2001). Self-Representations and Socioemotional Competence in Young Children: A 3-Year Longitudinal Study. Developmental Psychology, 37, 126-134. http://dx.doi.org/10.1037/0012-1649.37.1.126

Yağmurlu, B., \& Sanson, A. (2009). Parenting and Temperament as Predictors of Pro-Social Behavior in Australian and Turkish Australian Children. Australian Journal of Psychology, 61, 77-88. http://dx.doi.org/10.1080/00049530802001338

Walker, S., Berthelsen, D. C., \& Irving, K. A. (2001). Temperament and Peer Acceptance in Early Childhood: Sex and Social Status Differences. Child Study Journal, 31, 177-192.

Wichmann, C., Coplan, R. J., \& Daniels, T. (2004). The Social Cognitions of Socially Withdrawn Children. Social Development, 13, 377-392. http://dx.doi.org/10.1111/j.1467-9507.2004.00273.x 
Scientific Research Publishing (SCIRP) is one of the largest Open Access journal publishers. It is currently publishing more than 200 open access, online, peer-reviewed journals covering a wide range of academic disciplines. SCIRP serves the worldwide academic communities and contributes to the progress and application of science with its publication.

Other selected journals from SCIRP are listed as below. Submit your manuscript to us via either submit@scirp.org or Online Submission Portal.
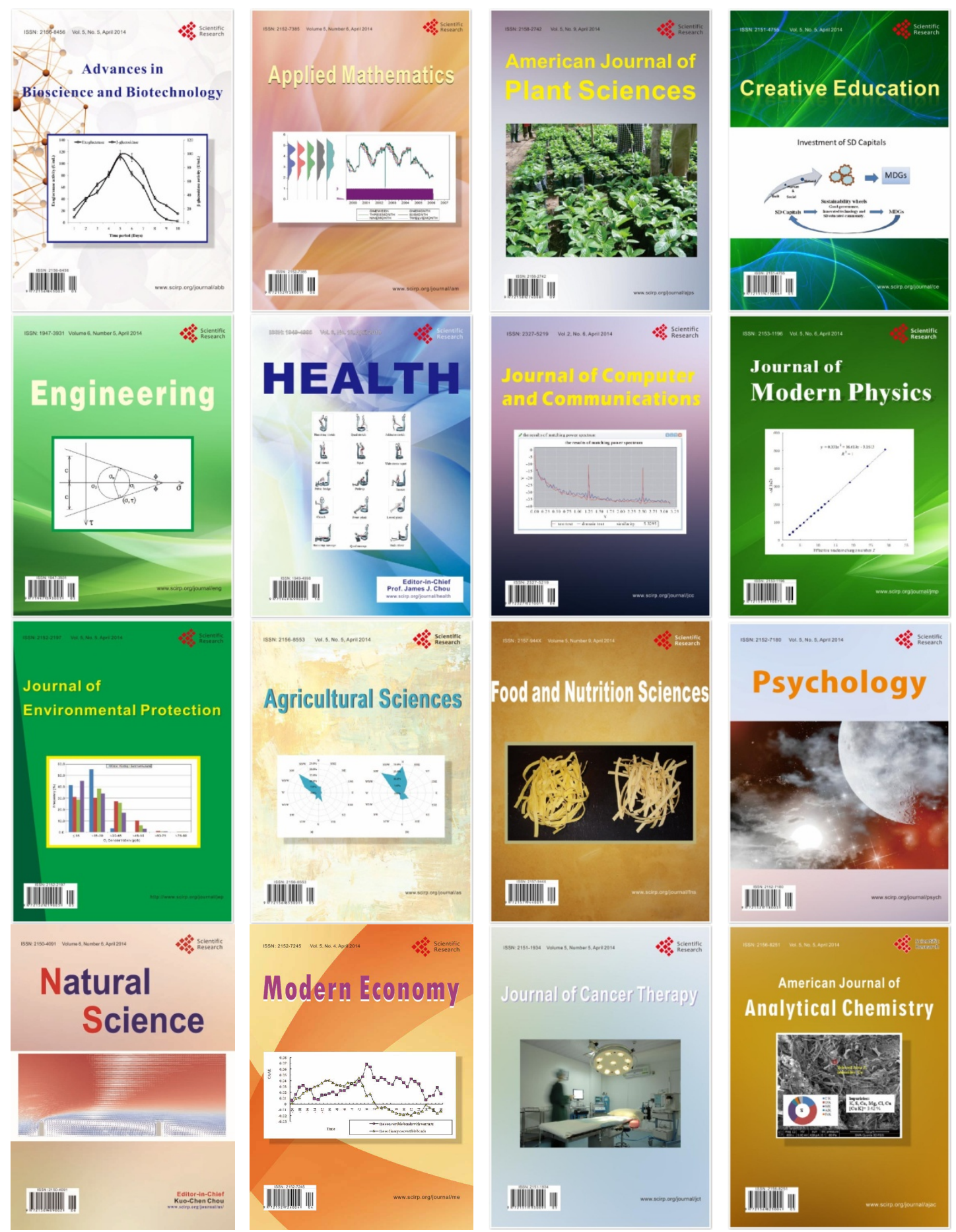